\title{
USING GRAPHIC ORGANIZER TO INCREASE STUDENTS' WRITING PERFORMANCE IN ORGANIZING IDEA
}

\author{
Winda Mayasari ${ }^{1}$, Sudarsono ${ }^{2}$, Yohanes Gatot Sutapa Yuliana ${ }^{3}$ \\ ${ }^{1}$ Master Study Program of English Education, ${ }^{23}$ Tanjungpura University \\ Correspondence email: windamayasari370@gmail.com
}

\begin{abstract}
The development of students' writing skill progresses from arranging some letters to becoming a simple word or phrase, such as writing a name, into a more complex text. This study was undertaken to describe two fundamental purposes related to the use of graphic organizer with eleventh-grade, normalachieving students: (a) to describe how does Graphic Organizer improve students' skill in organizing idea and (b) to describe how is the class situation when Graphic Organizer media is implemented in the writing class. The method carried out classroom action research. each procedure took some steps that formed one cycle and this research will be conducted in cycles. Each cycle is going to use Graphic Organizer as teaching media in writing activity. The subjects of the study are 32 students of social classes. Observation, interviews, questionnaires, and diary will be gathered respectively. The discussions on the students' problems in organizing ideas in writing in one side and on the benefits of Graphic Organizer as a solution to help students in organizing ideas in writing in the other side has encouraged the writer to conduct a classroom action research (CAR) on using Graphic Organizer to enhance students' skill in organizing ideas in writing class.
\end{abstract}

Keywords: writing skill, graphic organizer, classroom action research.

\begin{abstract}
Abstrak
Perkembangan keterampilan menulis siswa berkembang dari mengatur beberapa huruf menjadi kata atau frasa sederhana, seperti menulis nama, menjadi teks yang lebih kompleks. Studi ini dilakukan untuk menggambarkan dua tujuan mendasar terkait dengan penggunaan Graphic Organizer ke siswa kelas sebelas: (a) untuk menggambarkan bagaimana Graphic Organizer meningkatkan keterampilan siswa dalam mengorganisir ide dan (b) untuk menggambarkan bagaimana situasi kelas ketika media of Graphic Organizer diimplementasikan di kelas menulis. Metode penelitian yang dilakukan adalah penelitian tindakan kelas. Setiap prosedur mengambil beberapa langkah yang membentuk satu siklus dan penelitian ini akan dilakukan dalam satu siklus. Setiap siklus akan menggunakan Graphic Organizer sebagai media pengajaran dalam kegiatan menulis. Subjek penelitian adalah 32 siswa kelas sosial. Pengamatan, wawancara, kuesioner, dan buku harian dikumpulkan secara simultan. Diskusi tentang masalah siswa dalam mengorganisir ide-ide secara tertulis di satu sisi dan tentang manfaat Graphic Organizer sebagai solusi untuk membantu siswa dalam mengorganisir ide-ide dalam menulis, di sisi lain telah mendorong penulis untuk melakukan penelitian tindakan kelas (PTK). menggunakan Graphic Organizer untuk meningkatkan keterampilan siswa dalam mengatur ide-ide dalam kelas menulis.
\end{abstract}

Kata kunci: keterampilan menulis, Graphic Organizer, penelitian tindakan kelas. 


\section{INTRODUCTION}

To have an effective written text, a text should contain some aspects covering content, organization, grammar, vocabulary, and mechanics (Ghaith, 2002; Stone, 2016). It means that in producing a good text, students not only have grammatical knowledge but also bring up their content clearly and present it in an organization of ideas. A text can be classified as well-organized text if the text can fulfill the introductory paragraph. It has clear classification of what the text is going to describe. Each paragraph also has specific supporting materials. The text should be coherent, held together. To meet such text students are required to present (1) text structure (introduction, body, and conclusion), (2) paragraph development (clear point, specific supporting idea and concluding sentence), and (3) cohesive devices (Macintyre, 2007; Erdosy, 2003).

In fact, almost $70 \%$ of students in the writer's class find it difficult to organize ideas to be a well-written text, it can be seen from their daily test result less than 75 (Minimum criteria of mastery learning). Their difficulties come from their low ability in starting and arranging the text and in expressing their ideas into sentences or writing product. As a result, their undeveloped and unorganized writing is just scratched ideas. Besides, most of the students do not put the transitional signals for their texts. Consequently, the ideas are disconnected and this makes the readers lack guidance concerning the movement of one idea to the others. Other common problems they have are related to sentence structure, limited vocabulary, and grammar.

In more specific, the findings in the writer's personal classroom observation are that the students have fewer strategies in writing and their problems in organizing idea in English include (1) no clear point and specific supporting idea, (2) no transitional signal, (3) no appropriate generic structure of analytical exposition text. These problems may be caused by the writer as the actual teacher, the students, and the teaching-learning process.

From the teacher sides, the causes are (1) giving less portion of teaching organizing idea than other sub-skills of writing; and (2) do not use appropriate media to teach organizing idea; and (3) focusing more on acquiring the other skills such as reading 
and speaking rather than writing. In addition, the teacher does not give the students a good approach and treatment in writing and rarely uses media to help them to organize their ideas. Her teaching focuses on the text in the students' worksheet. She just asks them to write a composition based on the reading texts which have been learned. Moreover, her teaching of writing focuses on the teaching of grammar and vocabulary.

Some literature and research findings also have shown the usefulness of Graphic Organizer provides students with conceptual organizers in their writing. Through this Graphic Organizer, students make the outline of their writing in which the first draft or written outline improves the quality of the final written product (Graham \& Perin, 2007). Whereas, a strong and logical organization with flow and cohesiveness in the order of writing produces a good piece of writing (Borthwick, Nauman, \& Stirling 2011). Besides, the Graphic Organizer guide students to organize their ideas. In the view of, Herrell \& Jordan (2012) Graphic Organizer are visual or picture created to represent an idea, text, or connections between texts so that they are effective to brainstorm, plan, and organize writing. To Herrell \& Jordan, the teacher can use conceptual organizers to make ideas within an informational text more accessible to students. Students are required to think more analytically to lace individual characteristics and ideas in their proper position within the diagram. Outlines and charts provided students with guidelines and helped them produce better writings, and even, reduced the writing tensions. For example, a study by Donovan \& Smolkins' (2011) uncovers that outline-based formats helped students brainstorm and guide writing and, therefore, produce more developed and cohesive writing. Through using an outline to brainstorm facts for the writing, the outline guided students into the appropriate format.

Meanwhile, in a case study on fifth-grade students, Braun, Rajewski, \& Wiesendanger (2011), who implemented the Suggest-Plan-Choose strategy of writing and used outlines and charts to help students plan their writing, found that the use of outlines and charts eased the tension of writing and allowed students to write well-developed pieces of writing. 
In their study, Brown, Green, \& Lorenz (2009) uncovers two findings: (a) using a Graphic Organizer during the prewriting phase in a writers' workshop environment caused significant improvement for both high and low performing students and (b) students who used the Graphic Organizer to guide their pre-writing increased the quantity of their writing. Students who used Graphic Organizer in their writing produced significantly better writings than those who did not. Grabe \& Jiang (2007) through their case study of second language learning fourth-graders found that students who used the Graphic Organizer in the final writing piece were significantly better than those who did not use the organizer. The reasons were that the Graphic Organizer prompted the students thinking. Grabe and Jiang noticed that the Graphic Organizer could train student writers to not only write more proficiently but recognize more key components of the texts they read. Their research also found that Graphic Organizer allowed for a holistic understanding that words cannot convey. The organizational patterns of Graphic Organizer provide a scaffolding device that is beneficial to beginning writers. Graphic Organizer requires students to think farther and deeper.

The stages of the writing process were applied in this study. The GO is one of the prewriting media; in the main time, the implementation of it is stressed on the stage of prewriting (Oshima \& Hogue, 2007). Meanwhile, regarding the assessment, the study focused on the writing components - content and organization. Those two aspects are paramount importance to assess since they can establish the quality of the writing. Content is the substance and the essence of writing. It is the heart-beat of any great writing (Onukwugha, 2006). To develop the paragraphs students soundly organize the specific facts and ideas for making a well-written paragraph (Bramer \& Sedley, 1981). The discussions on the students' problems in organizing ideas in writing in one side and on the benefits of Graphic Organizer as a solution to help students in organizing ideas in writing in the other side has encouraged the writer to conduct a classroom action research (CAR) on using Graphic Organizer to enhance students' skill in organizing ideas in writing class. 


\section{RESEARCH METHOD}

The method carried out in this study is classroom action research. (Burns, 2010; Mills, 2000). Through this research, the writer realizes to overcome the students' problem in organizing ideas in writing. The writer will collaborate with another teacher in implementing the action research and will teach organizing ideas in writing in the implementation of the action research. Then she will discuss with her collaborator about the topic, the homework, exercises, and the test items. He will watch and observe the teaching-learning process. The practical action that the writer will use the Graphic Organizer to teach organizing idea.

The subject of this study is the eleventh-grade students at one of public-school in Sokan (West Kalimantan). The writer will choose this school as the setting of her research because she is the actual teacher, moreover, most students still have difficulties in English especially in organizing ideas in writing. The students have a low ability to starting and arranging the text. Most of the students have some ideas, but they have difficulties to arrange and express their ideas into sentences or written products. Besides, during her teaching, she gives less time for practicing the organizing ideas and applied the monotonous teaching media.

There are 32 students consisting of 18 boys and 14 girls. This classroom is wide enough for 32 students. This class will be selected based on my experience of being a teacher. The students still had a problem in writing especially in organizing ideas. The class situation was comfortable enough for studying. It has good lighting and complete facilities. In this classroom, there are LCD and sound system which are set permanently. There is also LCD screen to present the teaching material. The facilities are set as well as possible so it can be used easily. Besides that, there are whiteboards and blackboards in front of the class.

\section{FINDINGS AND DISCUSSION}

\section{Class Situation}

The researcher identified that the students' organizing ideas in writing skills needed to be improved. Therefore, Graphic Organizer was chosen and used as the teaching-learning media during the writing activity. It helps the students to produce a good piece of writing that has a strong and logical organization and is 
clear to the reader. The flow and cohesiveness in the order of writing are also key elements in good writing that is also concerned with the teaching media. Graphic Organizer is a visual or picture created to represent ideas, text, or connections between texts. The teaching media is effective to brainstorm, plan, and organize writing. In addition, the researcher can use conceptual organizers to make ideas within an informational text more accessible to students. Students are required to think more analytically to lace individual characteristics and ideas in their proper position within the diagram.

The target of using Graphic Organizer for the students is to improve the students' skill in organizing ideas. It can be measured through three aspects, they are paragraph development, text structure and cohesive devices. These three aspects are practically hand in hand in building coherence and cohesiveness of any text which is very fundamental to be mastered by students in order that their text quality in terms of coherency and cohesiveness becomes intelligible and acceptable.

The implementation of the research comprised of two cycles. Successively, there were four meetings for cycle 1 and four meetings for cycle 2 . The time allocation for each meeting was ninety minutes respectively. The teaching and learning activities covered pre-activities, main activities, and post activities. The use of a Graphic Organizer was implemented through the teaching and learning activities. The research process can be seen in table 1 .

Having reflected the students' problems in writing analytical exposition text and analyzed the result of the pre-research, the researcher made a plan for implementing the Graphic Organizer in writing class. The implementation of teaching writing using Graphic Organizer consisted of two cycles. The result of cycle 1 became the consideration in deciding and planning cycle 2 . Each cycle comprised four meetings and each meeting lasted for 90 minutes. 
Journal Homepage: http://journal.ikippgriptk.ac.id/index.php/bahasa Jurnal Pendidikan Bahasa, Vol. 8, No. 2, December 2019 Copyright (C IKIP PGRI Pontianak

Table 1. The overall Implementation of Cycle 1

\begin{tabular}{l} 
Description \\
\hline Cycle 1 \\
\hline Planning \\
1) Making lesson plan \\
2) Preparing the materials in teaching writing \\
3) Designing Post Test \\
\hline Acting \\
$\begin{array}{l}\text { Meeting 1: Building knowledge of the text, Introducing Graphic Organizers, modeling writing } \\
\text { analytical exposition by using Graphic Organizers, explaining and practicing the use } \\
\text { of cohesive devices in the sentence, arrange the jumble sentence into a good analytical } \\
\text { exposition. }\end{array}$
\end{tabular}

Meeting 2: Implementing Graphic Organizers in group: brainstorming, outlining, and drafting, revising, and rewriting

Meeting 3: Implementing Graphic Organizers in group: brainstorming, outlining, and drafting, revising, and rewriting

Meeting 4: Conducting Post Test

Observing Students

1) Some students still looked not curious with the materials

2) Afterwards, they looked enthusiastic in participating the activities

3) They looked active to draw Graphic Organizers.

4) They put their ideas in Graphic Organizers

5) They selected relevant and irrelevant ideas

6) They looked active in editing and revising their works

Teacher

1) Gave a model of the text

2) Explained the steps of writing and explained how to implement Graphic Organizers in writing

3) Invited the students to come up

4) Gave the students tasks

5) Facilitated the students in practicing the steps

Class Situation

1) Class was more interactive

2) The students were easily controlled

3) Most students were actively involved in the activities

4) Students were more confident

The Strengths

1) Organizing Ideas

a. The students' skill of organization in writing analytical exposition text improved significantly.

b. The score of students' text structure improved and reached the minimum standard

2) Class Situation

a. The students' motivation, confidence, and involvement in class improved.

The Weakness

1) Organizing Ideas

a. Some students could not arrange topic sentence and supporting sentence

b. Some students did not use various conjunction or references.

2) Class Situation

a. The writing process spent long time. This made students looked a bit bored of doing the teaching learning activity.

\section{The Students' Learning Progress}

The implementation of the Graphic Organizer in writing was able to improve the students' learning progress. Graphic Organizer which were implemented was helpful in improving the students' skill of organization in writing analytical exposition text. The indicators of paragraph development in Analytical exposition 
writing are paragraph development (the active topic sentence, the coherent supporting sentences and supporting details, and the active concluding sentence); the text structure (thesis, argument, and conclusion), and the use of cohesive devices. The result of the students' organizing ideas score stating cycle I can be seen in table 3.

Table 2. Test Scores of Organizing Idea in Cycle 1

\begin{tabular}{llccc}
\hline & Elements of Organization & researcher & Collaborator & Mean \\
\hline 1. & Text structure & 73 & 76 & 75 \\
\hline 2. & Paragraph Development & 68 & 72 & 74 \\
\hline 3. & Cohesive Devices & 69 & 72 & 71 \\
\hline & & 70 & 74 & 72 \\
\hline
\end{tabular}

Moreover, the improvement of the learning progress can be seen in table 4 .

Table 3. The Improvement of learning Progress in Cycle I

\begin{tabular}{llcc}
\hline \multirow{2}{*}{ No. } & Element of Organization & Pretest & Test Cycle 1 \\
\cline { 3 - 4 } & & Mean of inter-raters & Mean of inter-raters \\
\hline 1. & Text Structure & 70 & 75 \\
\hline 2. & Paragraph Development & 67 & 74 \\
\hline 3. & Cohesive Devices & 66 & 71 \\
\hline & & 67 & 72 \\
\hline
\end{tabular}

By observing the students' works, it was revealed that there were some results to be noted down. The improvements were; (1) the improvement in writing topic sentence; (2) the improvement in writing coherent supporting sentences; (3) the improvement in writing concluding sentence; (4) the improvement in using cohesion devices; and (5) the improvement in writing appropriate text structure (Thesis, argument, and conclusion). Table 4, proved that the students' mean score of the organization increased from 67 in the pretest to 72 in the test of cycle 1.

From cycle 1, it can be concluded that the score for text organization improves quite significantly and passed the passing grade. The improvement of the students' skill of organization could be seen from the result of test in cycle 1. First, the text structure improved from 70 in pre-cycle to 75 in cycle 1 . The improvement is signed by the students' ability to contextualize the text as a whole more intelligibly. They could maintain the topic of the text and put explanation not out of the topic being analyzed. The generic structure could also be followed systematically starting from thesis, argument, and reiteration. The inter-paragraph coherence started being concerned by them. Second, the smaller part of the text, 
particularly the paragraph development was also commonly also be welldeveloped. The average score improvement also occurred from 67 to 70 . The students could develop a paragraph suitable to its main idea. To support their paragraph development, examples are often used. However, it was also found the paragraph development was still not smooth. Commonly, because the genre is analytical exposition, the main idea development of each paragraph uses more detailed explanation and some examples. However, some other students, instead of analyzing the main idea, ended up with repeating the main idea by using the other words. It was found that just a few of them could give the explanation and examples overall relevant with the issue. Third, the cohesive devices was also the main concern. The average score improvement occurred from 65 in pre- cycle to 71 in the first cycle. The cohesive devices of the inter-paragraph, inter sentence, even inter words obtained serious attention from the students. Some of them started using more technical devices like "in addition" or "moreover" instead of "and." This was because they were introduced with various cohesive devices. However, it remains difficult for some other students proven by its average score which did not reach the minimum score stipulated to pass. They still found it quite confusing to connect one sentence to another. The tendency of using simple sentence was common though it is very potential to be chained with the next sentence. Repetition also still occurred signed by the frequency of using of reference was still less.

\section{The Improvement of the Teaching and Learning Process}

The researchers noted that there were some positive results from the implementation of Graphic Organizers in cycle 1 relating to the teaching and learning process. The result included; (1) the students learned that in the writing process, outlining by using Graphic Organizers is one of the steps that help them to arrange their ideas; (2) the students learned that the writing process did not take in once draft but it could be drafted in many times as long as the draft could be a good final writing; (2) the writing process gave more understanding to the students that there were many aspects of writing that should be focused on such as organization and content. Relating to the students' motivation and interest, some improvement could also be noted. The students were active in doing the tasks. 
They enjoyed the activities like drawing and putting their ideas in the Graphic Organizers, developing ideas from the Graphic Organizers and reducing some irrelevant ideas in the paragraph.

The activities like editing and revising were challenging for some students since they could prove their skill in English. By doing such kind of activities, they could identify the correct and incorrect writings. It meant they could show their skill to determine the correct or incorrect writing relying on their knowledge about writing, grammar, vocabulary and the like.

The researcher realized that there was improvement of the students' skill in organization. However, the researcher still found some problems as the weaknesses of cycle 1 . The students' paragraph development, cohesive devices and classroom situation still need to be improved. Accordingly, the researcher revised some plans related to the activities and materials in implementing Graphic Organizers. The revised plans were: (1) The researcher gave more explanation, and give more activities about the cohesive devices; (2) The researcher gave explanation, example, and exercise in arranging topic sentence and supporting sentence (paragraph development); and (3) The researcher implemented number head together technique to improve the students participation.

\section{Implementation of Cycle 2}

Cycle 2 was planned based on the revised plan in cycle 1 . The researcher tried to find the appropriate activities and some exercises to improve the students' difficulty that encountered in cycle 1 . In cycle 2, the researcher took the basic skill; the students are able to write analytical exposition text with good organization. The researcher prepared a lesson plan to guide the researcher in implementing the teaching and learning activities by using Graphic Organizers. Relying on the weaknesses in cycle 1 and the indicators, the researcher started some goals for the teaching and learning processes and designed additional activities and exercises for the students. The detail of the planning of the students' activity in cycle 2 could be seen in the table 4.7 
Journal Homepage: http://journal.ikippgriptk.ac.id/index.php/bahasa Jurnal Pendidikan Bahasa, Vol. 8, No. 2, December 2019

Copyright $\mathbb{C}$ IKIP PGRI Pontianak

Table 4 Planning of Students' Activity in Cycle 2

\begin{tabular}{|c|c|c|}
\hline \multirow{3}{*}{$\begin{array}{c}\text { Meeting } \\
\text { Meeting } 1\end{array}$} & Topic on Cycle 2 & Students' Activities \\
\hline & $\begin{array}{l}\text { Cohesive Devices Used in } \\
\text { Analytical Exposition }\end{array}$ & $\begin{array}{l}\text { Studying the cohesive devices used in analytical } \\
\text { exposition text by using Graphic Organizers } \\
\text { media and number head together technique. } \\
\text { Drilling the cohesive devices exercise: Mixed } \\
\text { and Match, Multiple Choices Identifying } \\
\text { Cohesive }\end{array}$ \\
\hline & & $\begin{array}{l}\text { devices in analytical exposition text, and filled } \\
\text { the }\end{array}$ \\
\hline Meeting 2 & Paragraph development. & $\begin{array}{l}\text { Practicing to arrange the topic sentence and } \\
\text { supporting sentence by using Graphic } \\
\text { Organizers } \\
\text { media and number head together } \\
\text { technique. Drilling to make topic sentence } \\
\text { and supporting }\end{array}$ \\
\hline Meeting 3 & $\begin{array}{l}\text { Practicing writing steps } \\
\text { in writing Analytical } \\
\text { exposition Text by using } \\
\text { Graphic Organizers; } \\
\text { Prewriting, } \\
\text { Outlining, drafting, }\end{array}$ & $\begin{array}{l}\text { Implementing Graphic Organizers and number } \\
\text { head together technique step by step: } \\
\text { Brainstorming, } \\
\text { Outlining (drawing Graphic Organizers and } \\
\text { put the ideas in the Graphic Organizers), } \\
\text { Drafting, Editing } \\
\text { and Revising the writing to reduce }\end{array}$ \\
\hline Meeting 4 & Conducting Test & $\begin{array}{l}\text { Taking test in writing analytical exposition text. } \\
\text { Submitting the works and evaluating the } \\
\text { teaching and learning process }\end{array}$ \\
\hline
\end{tabular}

\section{The Students' Learning Progress}

\section{students skill in organizing ideas}

Dealing with their problems in cohesive devices in the first meeting of cycle

2 , the researcher explained the way to make the whole text coherent. To make sure that they followed the materials, the researcher gave them some exercises. They did the exercises well and could finish all of the tasks given. This made the researcher satisfied and felt sure to continue to the next materials. The researcher concluded that their comprehension about cohesive devices grew better. Accordingly, the researcher went on the next effort in order to improve some lacks which were discovered in cycle 1 . The next meeting, the students were strengthened of the way to make the paragraph development. The researcher facilitated the students to improve their skill of organizing ideas. The skill of organization improved were 
writing effective topic sentence, writing logical supporting sentences, reducing irrelevant sentences with the topic sentence, using more conjunctions, and writing concluding sentence. The next meeting, the researcher asked the students to practice to write. In this meeting, the researcher also found progress in the students writing.

The next meeting was for the test. The students were asked to write an analytical exposition text. They described the reason why smoking is harmful for us. They should write at least three paragraphs. The time allocated was ninety minutes. The aspects of writing that were scored were specifically, the detail of students' skill in organizing ideas which scope 3 aspects namely te xt structure, paragraph development, and coherence. The students' score was depicted by table 5 .

Table 5 The Final Test Scores of Each Organizing Ideas Indicator in Cycle2

\begin{tabular}{lllll}
\hline \multicolumn{1}{c}{ Indicators } & Text & Paragraph & Cohesive & Mean score \\
\hline Rater 1 & 80 & 78 & 78 & 79 \\
\hline Rater 2 & 83 & 79 & 79 & 80 \\
\hline Mean Score & 80 & 77 & 78 & 80 \\
\hline
\end{tabular}

The table shows that the mean score of students' organizing ideas has reached the minimum standard. That is 80 . All of aspect of organizing ideas also had reached the minimum standard. The mean score of text structure was 80 , the mean score of paragraph development was 77 and the mean score of cohesive devices was 78 .

The result was shown in table 6. It revealed that students' skill of organization improved significantly. It was concluded from the indicators of the organization in the students' writing.

Table 6 The Result of Cycle 2

\begin{tabular}{l|l|l}
\hline No & \multicolumn{1}{|c|}{ Indicators } & Result \\
\hline 1. & The number of cohesive device used by the students. & Increased \\
\hline 2. & $\begin{array}{l}\text { All students' writings have effective topic sentence, } \\
\text { relevant supporting sentences, and have concluding }\end{array}$ & \\
\hline 3. & All students' writing have correct text structure & Increased \\
\hline
\end{tabular}


Regarding with the number of students that could reach-passing grade, the fact revealed that all students could reach the passing grade. In the cycle 1, 60.71 percent reached passing grade. In cycle 2, 100 percent students could reach passing grade. It means, all students reached passing grade in cycle 2. The result of computation for passing grade could be seen in the table 7

Table 7 Computation for Passing Grade

\begin{tabular}{lllllll}
\hline & \multirow{2}{*}{$\begin{array}{c}\text { No } \\
\text { grade }\end{array}$} & \multicolumn{2}{c}{ Explanation } & \multicolumn{3}{c}{ Number of students } \\
\cline { 3 - 5 } & & & The researcher $\begin{array}{c}\text { Second } \\
\text { rater }\end{array}$ & Inter rater & \\
\hline 1 & 75 & $\begin{array}{l}\text { Score above passing } \\
\text { Grade }\end{array}$ & 28 & 28 & 28 & $100 \%$ \\
\hline 2. & 75 & $\begin{array}{l}\text { Score below passing } \\
\text { Grade }\end{array}$ & 0 & 0 & 0 & $0 \%$ \\
\hline \multicolumn{5}{l}{ The overall progress of writing analytical exposition text }
\end{tabular}

Table 8 Student's Organizing Ideas Score Progress during the Research

\begin{tabular}{llcc}
\hline \multirow{2}{*}{$\begin{array}{c}\text { No. } \\
\text { Ideas }\end{array}$} & \begin{tabular}{c} 
Organizing \\
\cline { 3 - 4 }
\end{tabular} & $\begin{array}{c}\text { Cycle 1 } \\
\text { Mean of } \\
\text { inter- }\end{array}$ & $\begin{array}{c}\text { Cycle 2 } \\
\text { Inter- }\end{array}$ \\
\hline 1. & Text Structure & 75 & 80 \\
\hline 2. & Paragraph & 70 & 77 \\
\hline 3. & Cohesive Devices & 71 & 78 \\
\hline & & 72 & 80 \\
\hline
\end{tabular}

As the improvement tangibly occurred after the treatments were given to the students successively in cycle 1 and cycle 2 , some improvements deserved noting to make it easier to understand. To find out the improvement of the research that was conducted in the two cycles. 
Table 9 The Summary of the Results of the Class Action Research

\begin{tabular}{|c|c|c|c|}
\hline No & Pre-research findings & Cycle 1 & Cycle 2 \\
\hline 1 & $\begin{array}{l}\text { Improvement in } \\
\text { students' organizing } \\
\text { ideas skill }\end{array}$ & $\begin{array}{l}\text { Mean Score of Post test in } \\
\text { Cycle 1: } 72\end{array}$ & $\begin{array}{l}\text { Mean Score of Post Test } \\
\text { in Cycle 2: } 80\end{array}$ \\
\hline 2 & $\begin{array}{l}\text { Achievement of all } \\
\text { writing elements } \\
\text { Text Structure } \\
\text { Paragraph } \\
\text { Development } \\
\text { Cohesive devices }\end{array}$ & $\begin{array}{l}75 \\
70 \\
71\end{array}$ & $\begin{array}{l}80 \\
77 \\
78\end{array}$ \\
\hline 3 & Mean & 72 & 80 \\
\hline 4 & $\begin{array}{l}\text { The students' skill of } \\
\text { organization in } \\
\text { writing analytical } \\
\text { exposition text. }\end{array}$ & $\begin{array}{l}\text { Students could not write } \\
\text { effective topic sentences } \\
\text { could not irrelevant } \\
\text { supporting sentences. } \\
\text { write effective concluding } \\
\text { sentence. } \\
\text { difficulty in text structure } \\
\text { could not implement the } \\
\text { use of cohesive devices }\end{array}$ & $\begin{array}{l}\text { Students could write topic } \\
\text { sentences. } \\
\text { relevant supporting } \\
\text { sentence. } \\
\text { The students could not } \\
\text { write effective } \\
\text { concluding sentence. } \\
\text { The students could } \\
\text { develop the text structure. } \\
\text { The students could } \\
\text { implement the use of } \\
\text { cohesive devices }\end{array}$ \\
\hline 5 & $\begin{array}{l}\text { Improvement in class } \\
\text { Situation }\end{array}$ & $\begin{array}{l}\text { Students took long time to } \\
\text { write Analytical Exposition } \\
\text { text } \\
\text { passive in teaching learning } \\
\text { process. } \\
\text { interest in teaching learning } \\
\text { process. }\end{array}$ & $\begin{array}{l}\text { The learning process } \\
\text { become more effective } \\
\text { and efficient. The } \\
\text { students } \\
\text { were active in teaching } \\
\text { learning process. The } \\
\text { students } \\
\text { were interest in teaching } \\
\text { learning process. }\end{array}$ \\
\hline
\end{tabular}

After analyzing the result of the research, the researcher and the collaborator agreed that the implementation of Graphic Organizers in developing students'skill in organizing ideas was already successful, and it was time to stop the research. The indicator of the success could be seen from: (1) the mean score of students' skill in organizing ideas has improved; (2) The scores of organizing ideas' indicators have improved; (3) The students become more effective and efficient; (4) The students participation in learning English enhanced; and (5) the class situation become more conducive. 


\section{DISCUSSION}

Writing analytical exposition text, like writing many other kinds of texts, have some elements to be regarded as a good writing. One of the important elements of writing analytical exposition text is the skill in organizing ideas or the skill in arranging and developing ideas coherently. Organization in writing refers to the order of ideas and the way they are arranged one to another. It is very important to help the students to develop their organizing idea. As one of the elements in writing, organization must be concerned by researcher because it is very important in delivering information and meaning to the readers. Therefore, a text must has good organization. There are some indicators to measure whether a text has a good organization. The indicators are: paragraph development (effective topic sentence, coherent supporting sentences, and effective concluding sentence), the use of cohesive devices, and text structure (Thesis, argument, and conclusion).

Responding the indicators, in the implementation of Graphic organizers in cycle 1 and cycle 2, the researcher finds several facts. One of the facts is that the activities in Graphic Organizers worked well in improving the students' skill of organization. The students could improve their skill of organizing ideas in writing analytical exposition text in cycle 1 and in cycle 2 . The improvement of skill can be identified from the score and the students writing skill. The score in cycle 1 is better than the score in pretest and the score in cycle 2 is better than the score in cycle 1 .

Another fact is that the teaching and learning process in writing class is better compared to the previous process before the Graphic Organizers were implemented. The implementation of Graphic Organizers in teaching and learning writing became more interesting and encouraging. Before the treatment, there were many students who were not interested in writing class. This situation made the teaching and learning process not encouraging. Some students assumed that writing was boring activity. However, after implementing Graphic Organizers in teaching and learning writing, there were some improvements in the students' participation and motivation in learning and practicing writing. They became more 
enthusiastic and active in doing the steps and the activities in writing class. From the beginning till the end of the lesson, the students were involved actively.

The facts that were found in this study, the implementation of Graphic Organizers can improve the students' skill of organization in writing analytical exposition text. Graphic Organizers are the media to enhance the students' writing skill in organizing ideas. Through the activities in Graphic Organizers, the students' skill of organizing ideas improved. As the media used in the process of pre-writing, graphic organizers can help the students produce and organize the ideas before they start to write. In the process of pre- writing, Graphic Organizers provide diagrams or columns to organize their ideas and make the outline. The students can put introduction, body, and conclusion in sequence correctly. After the students put the central ideas, the students put the sub ideas in the graphic. It can be seen in the process of making Graphic Organizers, the sub ideas occur after the researcher determines the central idea. It means that the ideas are systematic and consistent with the theme that has been determined.

Students' attitudes toward writing, their usage of word choice, and organization improved. Most students gain success in writing when using prewriting strategies such as Graphic Organizers took place in cycle II. In addition, Graphic Organizers can also improve the three aspect of organizing ideas. Those are text structure, paragraph development, and cohesive devices.

The first organizing ideas indicator is cohesive devices. In this aspect, the students seem to be hard to find the appropriate cohesive devices. Graphic Organizers can improve the students' mastery of the cohesive devices. The Graphic Organizers help the students to visualize, distinguish, and memorize the cohesive devices material. Therefore, the students can easily recall and implement the cohesive devices in the sentence. Thus, the students' writing becomes more coherent.

This finding is supported by the theory from McKnight. McKnight (2010) stating that the Graphic Organizers are visualizations of these mental storage systems, and serve to support students in remembering and connecting information. Since the students have remembered and understood the concept of 
cohesive devices, the students can easily implement the cohesive devices in the sentences.

This finding is supported by Lancaster (2013) stating that by using Graphic Organizers students will be able to organize their story with a beginning, middle, and end and learn to select words for their chosen topic. Moreover, Santangelo \& Olinghouse (2009) suggest that the use of Graphic Organizers to encourage the generation of ideas and improve the organizational structure in students' writing. Graphic Organizers help the students to organize the ideas from the beginning into the end of the story.

The other strength of using Graphic Organizer is students can connect main idea and supporting ideas well as well as the topic idea and supporting ideas as well. This is because Graphic Organizers show the connection between main topic and its supported ideas (Hall \& Strangman, 2002). Accordingly, it helps the students organize the ideas into good sentences. When the students have made the sentences, it make easier in arranging the sentences into a good paragraph. The connection of each idea also helps the students focus in the main topic and reduce unsupported ideas.

When implementing Graphic Organizers, the problems regarding to the process of teaching and learning can be overcome. First, the process become more encouraging since the students' participation in the activities increase. Before the treatment, just a few of them asked and responded to the teacher's explanation and the example of writing but the number significantly increased when they practice the Graphic Organizers. All of the students became active in the teaching learning process.

Second, the teaching learning process became efficient and effective. Graphic Organizers help the students to link between their knowledge and ideas into their writing. The students can easily organize their ideas so that the writing process became faster and got better result. This finding was supported by Dye (2000). She states that Graphic Organizers provide students with a road map to follow as they expand their schemas by linking them to existing knowledge. In addition, Iranmehr, et all (2011) also state that Graphic Organizers help the students to 
organize the students' thought. The ideas cannot disappear easily when the students organize their ideas into Graphic Organizers. Graphic Organizers also helps the students remember the ideas that connect each other. As the result, the students will need less time to finish their writing when they have got the ideas fast.

Third, the students have high motivation in teaching learning process, they enjoyed the teaching learning process. The students are also more interested in following the process. In the steps of outlining and drafting, they draw Graphic Organizers and put their ideas in it. Then they develop the ideas into sentences successively. This finding is in line with the research conducted by Lee \& Tan (2010) who state that there is an interaction between Graphic Organizers and learning motivation. The students who have high motivation will get the better result if they thought by using Graphic Organizers. In Graphic Organizers the students are encouraged and motivated to be active students. They are given task to make meaningful graphic. They are encouraged to write topic on their paper and brainstorm the topic into a good paragraph. By using Graphic Organizers the students having high motivation will be interested in learning writing organization. It is also in line with the research conducted by Sundeen (2007). The result of her research states that Honeycomb Graphic Organizers contribute to the development of the positive attitude in writing analytical exposition text. The students' positive attitude in writing analytical exposition text improved. The students become more attracted to write analytical exposition text. They positively respond to the lesson and enjoy it very well.

Moreover, this finding is also supported by Zubaidah, Fuad, Manahal \& suarsini (2017). They state that the utilization of Graphic Organizer changes crucial behavior toward writing. Graphic Organizer makes meaning, and as an advanced organizer, it can make learning meaningful. They furtherly express, that in order for "meaningful learning" to occur the individual must have established learning by determining if the information received is meaningful. If this information is meaningful, then the individual will process the information and this will strengthen his/her knowledge. Since positive result toward changing students' attitude is derived then each student experienced meaningful learning. From the 
orientation about writing requires serious efforts to be learned, it turns out that writing can be viewed as fun and exciting subject.

This research tries to clarify the other previous research. The other previous research said that Graphic Organizers is one of tools that help the students to improve their writing skill. The current research proves the previous research that Graphic Organizers is an effective tool to improve the students' writing skill. By using Graphic Organizers, the students could prepare to write earlier. In the term of writing steps, Graphic Organizers help the students in the pre-writing stage, Graphic Organizers help the students to improve students' skill in organizing idea. The result of the current research justifies the other previous research findings, Graphic Organizers help the students to prepare writing earlier. By early preparation, the result of the students writing become more cohesive, coherent, and creative.

\section{REFERENCES}

Borthwick, A., Nauman, A. D., \& Stirling, T. (2011). What makes writing good? An essential question for teachers. The Reading Teacher, 64(5), 318-328.

Braun, G., Perry, J. R., \& Wiesendanger, K. D. (2011). Suggest-choose-plancompose: A strategy to help students learn to write. The Reading Teacher, 64(6), 451- 455 .

Bramer, G. R., \& Sedley, D. (1981). Writing for readers. Merrill Pub Co.

Brown, A., Green, T., \& Lorenz, B., (2009). Using multimedia graphic organizer software in the prewriting activities of primary school students: What are the benefits?. Computers in the Schools, 26(2), 115-129.

Burns, A. (2010). Collaborative Action Research for English Language Teachers. Cambridge: Cambridge University Press.

Donovan, C. A., \& Smolkin, L. B. (2011). Supporting informational writing in the elementary grades. The Reading Teacher, 64(6), 406-416.

Dye, G. A. (2000). Graphic organizers to the rescue! Helping students link - and remember-information. Teaching Exceptional Children, 32(3), 72-76. 
Erdosy, M. U. (2003). Exploring variability in judging writing ability in a second language: A study of four experienced raters of ESL compositions. ETS Research Report Series, 2003(1), i-62.

Ghaith, G. (2002). The nature of the writing process. Online at nadabs. tripod. com/ghaith-writing. htm.

Grabe, W., \& Jiang, X. (2007). Graphic Organizers in reading instruction: Research findings and issues. Reading in a Foreign Language, 19(1), 34-55.

Graham, S., \& Perin, D. (2007). What we know, what we still need to know: Teaching adolescents to write. Scientific Studies of Reading, 11(4), 313-335.

Hall, T., \& Strangman, N. (2002). Graphic organizers. National Center on Accessing the General Curriculum, 1-8.

Herrell, A. L., Jordan, M. L., \& Eby, J. W. (2012). Teaching in the elementary school: A reflective action approach. Pearson Higher Ed.

Irhanmehr, Abutaleb., Davari, Hossein., Erfani, Syted, Mahdi. (2011). The Application of Organizers as an Efficient Technique in ESP Textbooks Development. Theory and Practice in Language Studies, Vol. 1, No. 4, pp. 417-422.

Lancaster, K. (2013). An examination of using graphic organizers to teach writing: A case study. Research in Action, 2, 1-42.

Lee, C. C., \& Tan, S. C. (2010). Scaffolding writing using feedback in students' graphic organizers-novice writers' relevance of ideas and cognitive loads. Educational media international, 47(2), 135-152.

Macintyre, R. (2007). Revision of Criterion-Referenced Rating Scale Used to Assess Academic Writing. Studies in Linguistic and Language Teaching, 18, 203-219.

McKnight, K. S. (2010). The teacher's big book of graphic organizers: 100 reproducible organizers that help kids with reading, writing, and the content areas. John Wiley \& Sons.

Onukwugha, U. (2006). The Four Cardinal Points of Any Good Writing: Expression, Content, Organization \& Technical Accuracy (online). URL: http://ezinearticles.com/?The-Four-Cardinal-Points-of-Any-Good-Writing. (Accessed on 2 October 2019). 
Santangelo, T., \& Olinghouse, N. G. (2009). Effective writing instruction for students who have writing difficulties. Focus on exceptional children, 42(4).

Sundeen, T. H. (2007). So What's the Big Idea? Using Graphic Organizers to Guide Writing for Secondary Students with Learning and Behavioral Issues. Beyond Behavior, 16(3), 29-34.

Stone, C. A., Silliman, E. R., Ehren, B. J., \& Wallach, G. P. (Eds.).

(2016). Handbook of language and literacy: Development and disorders.

Guilford Publications.

Zubaidah, s., fuad, n. M., mahanal, s., \& suarsini, e. (2017). Improving creative thinking skills of students through differentiated science inquiry integrated with mind map. Journal of Turkish Science Education, 14(4), 77-91. 